\title{
Test Excavations at 41HE257, Henderson County, Texas
}

\author{
E. Frances Gadus
}

Follow this and additional works at: https://scholarworks.sfasu.edu/ita

Part of the American Material Culture Commons, Archaeological Anthropology Commons, Environmental Studies Commons, Other American Studies Commons, Other Arts and Humanities Commons, Other History of Art, Architecture, and Archaeology Commons, and the United States History Commons

Tell us how this article helped you.

This Article is brought to you for free and open access by the Center for Regional Heritage Research at SFA ScholarWorks. It has been accepted for inclusion in Index of Texas Archaeology: Open Access Gray Literature from the Lone Star State by an authorized editor of SFA ScholarWorks. For more information, please contact cdsscholarworks@sfasu.edu. 


\section{Test Excavations at 41HE257, Henderson County, Texas}

\section{Licensing Statement}

This is a work produced for the Texas Department of Transportation (TxDOT) by the report producer. TxDOT and the report producer jointly own all rights, title, and interest in and to all intellectual property developed under TXDOT's contract with the report producer. The report may be cited and brief passages from this publication may be reproduced without permission provided that credit is given to both TxDOT and the report producer. Permission to reprint an entire chapter, section, figures or tables must be obtained in advance from either the Supervisor of the Archeological Studies Branch, Environmental Affairs Division, Texas Department of Transportation, 125 East 11th Street, Austin, Texas, 78701 or from the report producer. 


\author{
by \\ E. Frances Gadus
}

Principal Investigator: Ross C. Fields

TECHNICAL REPORTS, NUMBER 64

Prewitt and Associates, Inc.

Cultural Resources Services

Austin, Texas

ARCHEOLOGICAL STUDIES PROGRAM, REPORT 55

Texas Department of Transportation

Environmental Affairs Division

October 2003

ISBN 1-930788-24-X 


\title{
TEST EXCAVATIONS AT 41HE257, HENDERSON COUNTY, TEXAS
}

\author{
Copyright (C) 2003 \\ Texas Department of Transportation (TxDOT)
}

TxDOT owns all rights, title, and interest in and to all data and other information developed for this project. Brief passages from this publication may be reproduced without permission provided that credit is given to TxDOT. Permission to reprint an entire chapter, section, figures or tables must be obtained in advance from the Supervisor of the Archeological Studies Program,

Environmental Affairs Division, Texas Department of Transportation, 125 East $11^{\text {th }}$ Street, Austin, Texas, 78701. Copies of this publication have been deposited with the Texas State Library in compliance with

State Depository requirements.

jointly published by the

Texas Department of Transportation

Environmental Affairs Division

Archeological Studies Program

Owen Lindauer, Ph.D., Supervisor

Archeological Studies Program, Report No. 55

and

Prewitt and Associates, Inc.

Cultural Resources Services

Austin, Texas

Technical Reports, No. 64

Contract \#572XXSA005, Work Authorization \#57214SA005

Printed at AccuGraphics in Austin, Texas 


\section{TABLE OF CONTENTS}

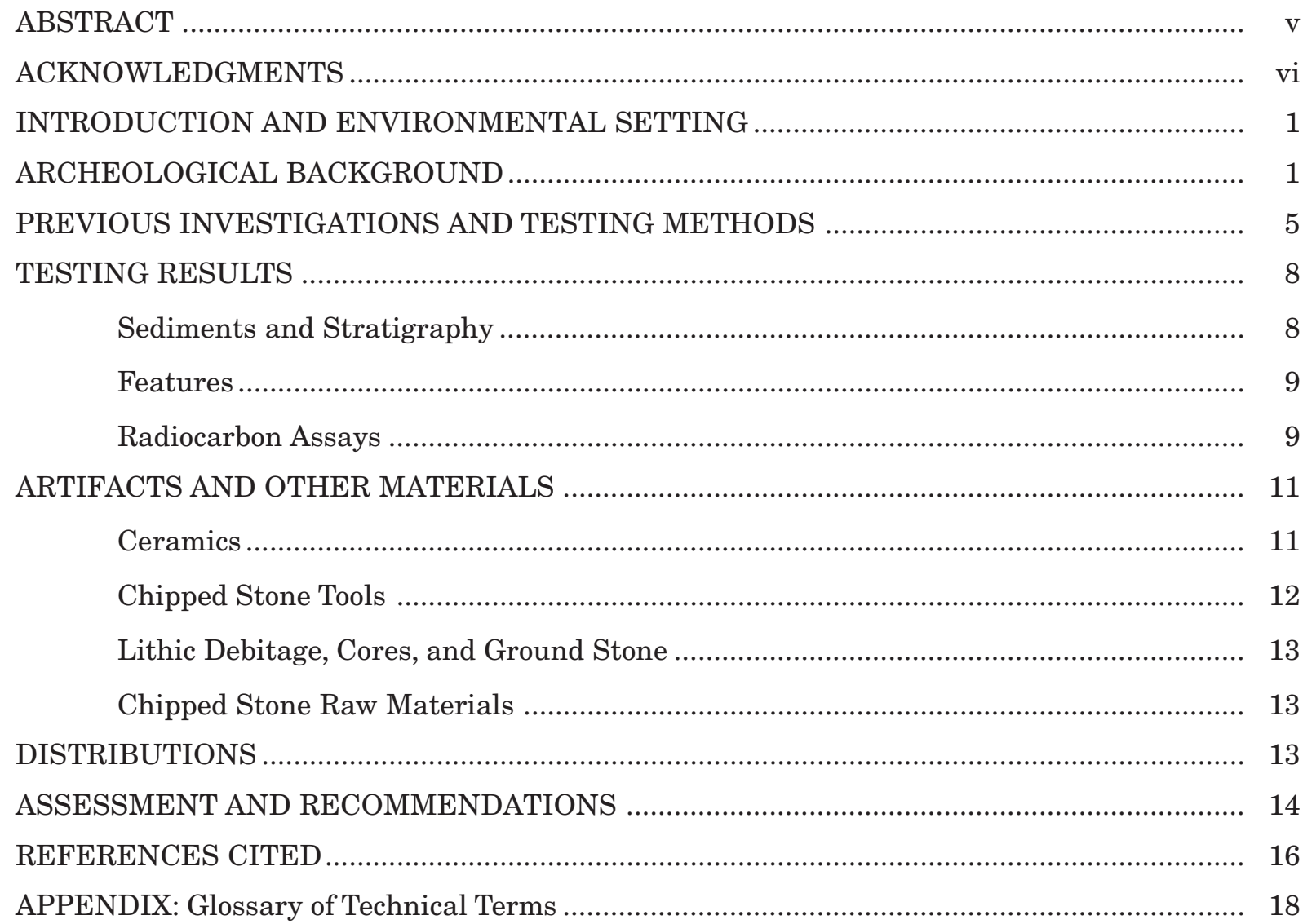




\section{LIST OF FIGURES}

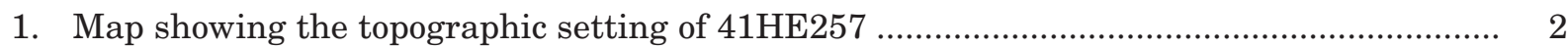

2. Plan of 41HE257 showing 2002 shovel test excavations ..................................................... 6

3. Topographic map of 41HE257 showing 2003 test excavations .......................................... 7

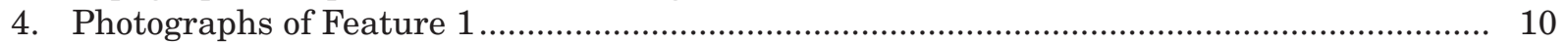

5. A carinated rim sherd and projectile points from 41HE257 ......................................... 12

\section{LIST OF TABLES}

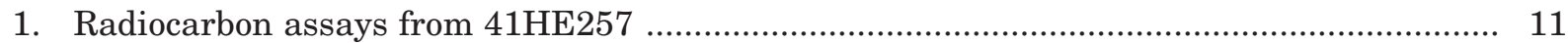

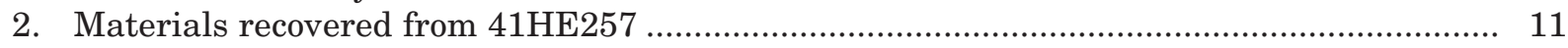

3. Distribution of debitage and ceramics at 41HE257 ....................................................... 13

4. Distribution of ironstone and quartzite pebbles at 41HE257 ......................................... 14 


\begin{abstract}
Personnel from Prewitt and Associates, Inc., conducted test excavations at 41HE257, a prehistoric site located in central Henderson County. This work was conducted for the Texas Department of Transportation (TxDOT), Environmental Affairs Division, since part of the site is within the right of way for the southern expansion of FM 317, the Athens Loop. The work was done under Texas Antiquities Permit No. 3070 and all materials collected and records generated are curated at the Texas Archeological Laboratory, The University of Texas at Austin. The excavations showed that the site is shallow and contains few lithics or ceramic artifacts, limited botanical remains, no faunal remains, and only one possible rock feature. One radiocarbon assay indicates the presence of an early Late Prehistoric component. However, that component could be mixed with earlier and later materials, and definition of discrete components is not possible. As such, the site has little capacity to yield important information and is considered ineligible for listing in the National Register of Historic Places or designation as a State Archeological Landmark.
\end{abstract}




\section{ACKNOWLEDGMENTS}

Recognition and thanks are due to the individuals whose efforts brought this project to a successful conclusion. Ms. Cindy Tennis, archeologist for the Texas Department of Transportation, Environmental Affairs Division and Mr. Jay Tullos of the TxDOT Tyler District Office provided excellent coordination and arranged for the Gradall used for stripping the site. Dr. James T. Abbott, geoarcheologist for the Environmental Affairs Division coordinated the analysis of the radiocarbon assays from the site.

Prewitt and Associates project staff consisted of the following: Ross C. Fields, principal investigator; E. Frances Gadus, project archeologist; and Weldon W. Hammond III, Gregory LaBudde, and Rachel Davies, field crew.

Thanks also go to the laboratory and office staff. Ms. Gadus analyzed and described all the artifacts. Jonathan Grant (under the direction of Karen M. Gardner) organized, processed, and

curated all recovered materials. Ms. Gardner also was responsible for the curation of all records. The excellent graphics presentation is due to Sandra L. Hannum. This report was edited by Audra L. Pineda and Mr. Fields, and the report was produced by Ms. Pineda. 


\section{INTRODUCTION AND ENVIRONMENTAL SETTING}

Testing of site 41HE257 to assess its eligibility for listing in the National Register of Historic Places and designation as a State Archeological Landmark was conducted during the first week of March 2003 by Prewitt and Associates, Inc. This work was carried out for the Texas Department of Transportation (TxDOT), Environmental Affairs Division, under Contract No. 572XXSA005 (Work Authorization No. 57213SA005) and Antiquities Permit No. 3070 from the Texas Historical Commission. The work was done to aid TxDOT in complying with Section 106 of the National Historic Preservation Act and the Antiquities Code of Texas. The site is in the west-central part of Henderson County approximately $5.0 \mathrm{~km}$ west-southwest of Athens, Texas (Figure 1). At least part of the site is in the right of way for the proposed southern extension of FM 317, the Athens Loop, and may be disturbed by that construction project. Investigations were restricted to the part of the site within the right of way, but beyond the right of way the possibility of extensive intact remains appears limited by slope erosion and construction of homestead improvements by the current landowner.

Site 41HE257 is situated on an interfluve knoll overlooking an intermittent tributary of Walnut Creek. The general area is a highly dissected upland with an elevation range of 360 to $580 \mathrm{ft}$ above sea level. The site itself is at ca. $390 \mathrm{ft}$ above sea level within $100 \mathrm{~m}$ of the Walnut Creek floodplain; the floodplain is narrow at this point at ca. $300 \mathrm{~m}$ across. From the site area, Walnut Creek flows ca. $10 \mathrm{~km}$ west to its confluence with Cedar Creek, a major tributary of the middle Trinity River. Cedar Creek continues another $5 \mathrm{~km}$ southwest of its Walnut Creek confluence to join the Trinity River. As such, 41HE257 is positioned on the eastern edge of the middle Trinity River drainage basin.

Walnut Creek and its tributaries cut the Eocene Wilcox Formation, which consists mostly of silty and sandy clay with localized beds of clay, lignite, silt, and quartzite sand (Bureau of Economic Geology 1965, 1972). Concentrations of calcareous siltstone and ironstone are common within this formation. Outcrops of massive ironstone are visible on several of the knoll tops overlooking the Walnut Creek valley. These expo- sures are visible from County Road 1500 west of 41HE257.

The soil associated with these knoll tops and the site area is mapped as Woodtell loam. This soil is described as having a 20-cm-thick surface layer of slight to medium acidic, very dark grayish brown loam to brown loam above a strongly acidic red clay with brownish yellow mottles (Hatherly and Mays 1979:36, 66).

The Woodtell soil and similar upland soils with sandy or loamy surface layers cover 63 percent of mainly eastern Henderson County and support a hardwood forest cover of post oak and blackjack oak with an understory of tall grasses and forbs (Hatherly and Mays 1979:3). Such vegetation is common to the Post Oak Savannah, which extends in a variable band southwest from the Red River to south-central Texas (Correll and Johnston 1979:4-6). A thin strip of this zone, ca. $80 \mathrm{~km}$ east to west, encompasses $41 \mathrm{HE} 257$ and is sandwiched between the Pine Forests of east Texas and the Blackland Prairie of central Texas (Correll and Johnston 1979:Map 1). The proximity of these three zones and their associated biotic resources place 41HE257 within a resource-rich area. Of particular importance to prehistoric inhabitants would have been the acorn- and hickory-nutproducing trees of the Post Oak Savannah and the concomitant abundance of deer, birds such as turkey, and small mammals such as cottontail rabbits. Bruseth et al. (1987:249-250) consider these abundant resources to be factors in the persistence of hunting and gathering economies throughout prehistory in this section of Texas.

Presently, the site area, having been cleared of natural vegetative cover in the recent past, supports pasture grasses with a scatter of hardwoods and cedar trees. To the west and north of the site, second-growth forest follows the course of Walnut Creek and its tributaries. A thicket of small cedars, oaks and greenbriers has formed around a large oak tree that is central to the site. The root systems of this large oak and thicket are likely preventing soil erosion from the central part of the site, as well as creating a major obstruction to site exploration.

\section{ARCHEOLOGICAL BACKGROUND}

The location of 41HE257 in the Post Oak 


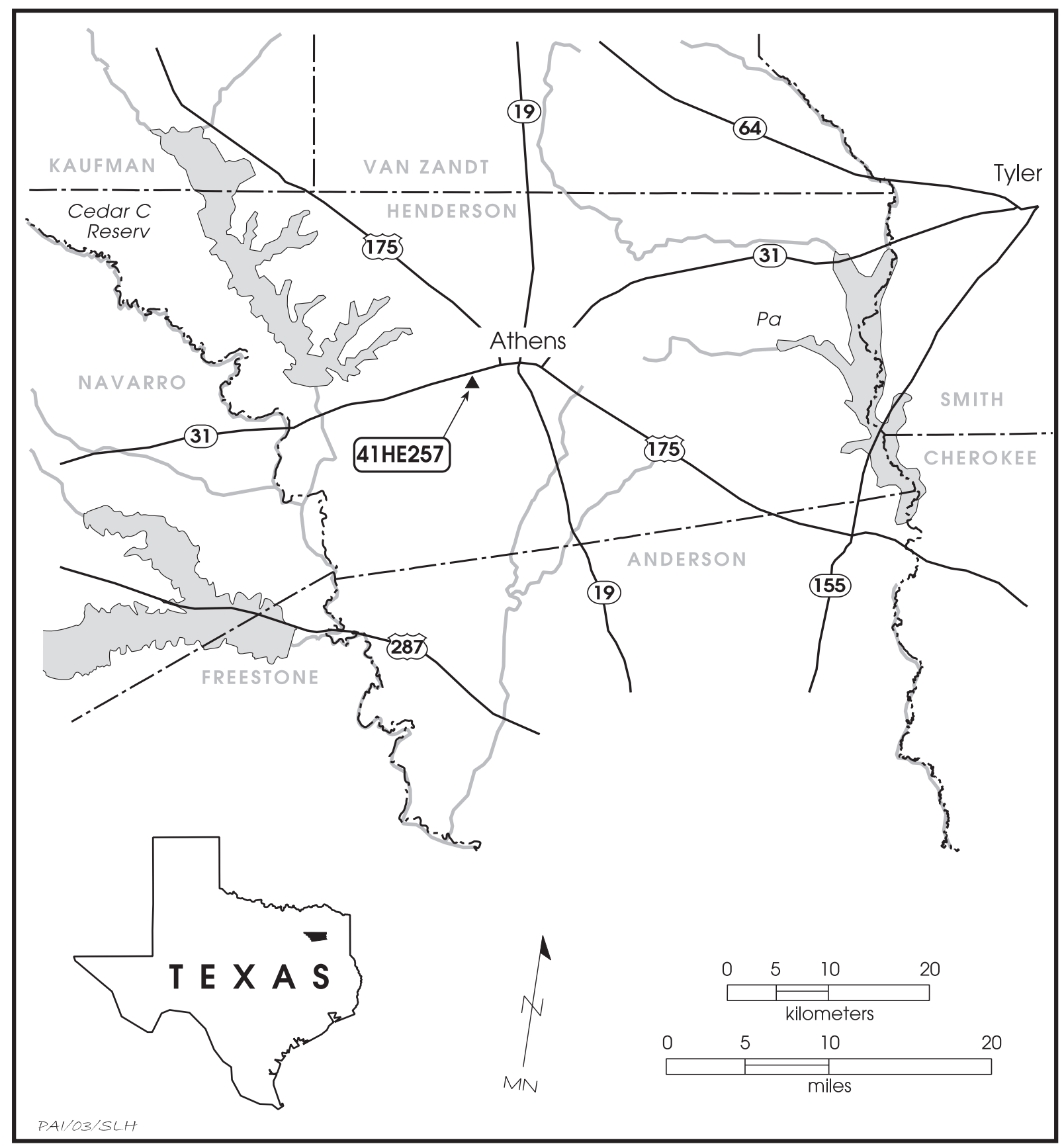

Figure 1. Map showing the general location of 41HE257.

Savannah at the edge of the middle Trinity River basin places it near several large reservoirs that have undergone various levels of archeological investigation. Much of what can be understood about prehistory in the middle Trinity basin and adjacent uplands, including central Henderson County, can be drawn from these investigations. Reservoirs in the Trinity
River drainage include Cedar Creek ca. $11 \mathrm{~km}$ to the northwest of 41HE257, Richland Chambers Reservoir ca. $29 \mathrm{~km}$ to the southwest, and Lake Palestine ca. $37 \mathrm{~km}$ east of 41HE257. Richland Chambers Reservoir was the only part built of a grand reservoir system proposed for the middle Trinity basin and given the appellation "Tennessee Colony Lake." The Tennessee 
Colony Lake, if it had been built, would have been linked to the existing Cedar Creek Reservoir and had a flood pool covering 149,000 acres in a four-county area including most of the western edge of Henderson County (Richner and Lee 1975:1-3).

Several themes have emerged from the prehistoric data gathered by these reservoir investigations. These themes include persistent technologies, settlement mobility vs. sedentism, and the effects - or lack thereof - of intergroup interactions. All three themes are integral to the identification of what Dee Ann Story (1965) recognized as the distinct cultural trajectory of the Post Oak Savannah. The identification and explanation of these themes, however, has only been possible set against a solid chronological framework that has been continually adjusted by the addition of new data, much of which has also come from the reservoir investigations. The themes and associated chronology form the basis of the following discussion. Note that the years B.C./A.D. attributed to the particular archeological periods referred to are based on the Richland Chambers data (McGregor 1987a:11-19).

Investigations at Cedar Creek Reservoir produced initial data concerning technology as associated with specific chronological periods for western Henderson County. Dee Ann Story (1965:163-257), working with the Texas Archeological Salvage Project of The University of Texas at Austin excavated three sites in the Cedar Creek bottoms. Sites 41HE61 (Wild Bull) and 41HE70 (Lacy) were in the central part of the reservoir, while 41KF7 (Gossett Bottoms) was just across the Henderson County line. All three were moderately thick $(0.3-0.9 \mathrm{~m})$, multicomponent sites that produced extensive and diverse artifact assemblages. The kinds of tools recovered include knives, gouges, scrapers, burins, microliths, gravers, drills, atlatl weights, celts, pitted stones, hammerstones, and abraders. Arrow points and dart points were common, as were plain and decorated ceramic vessel sherds (Story 1965:238).

The oldest artifacts recovered came from 41HE61. Story (1965:249) reports a Folsom-like dart point medial section, a basal fragment of an Eden-like point, rectangular- and expandingstem dart points, and Gossett and Clear Fork gouges and a Mineola end scraper. These artifacts, recovered from mixed contexts, are suggestive of an ephemeral Paleoindian period
(8000-6000 B.c.) occupation and an Early Archaic (6000-3000 B.c.) occupation. Early periods appear to be minimally represented within all the reservoir project areas under consideration here (Anderson 1972:161; Bruseth et al. 1987:233).

The Late Archaic and probably the transitional Late Archaic (1000 B.C.-A.D. 900) are represented at the three sites by the presence of Gary dart points and Bristol bifacial tools. Though Gary points are also known to occur with early ceramics, Story argues (1965:250) for a preceramic association of the components marked by a preponderance of Gary points in the lower levels at 41HE61 and 41KF7. These lower levels produced only small numbers of sherds. Story (1965:252) could not typologically define these sherds as "early ceramics," nor did she believe they were unequivocally associated with the Late Archaic occupation. It is also possible that the sherds and Gary points represent an early Late Prehistoric period (A.D. 900-1300) component. The recovery of Scallorn and Granbury arrow points also suggests that an early Late Prehistoric period component was present.

Though reflective of some component mixing, Story's (1965:251) artifact frequency charts for the two sites show the persistence of the Gary point into the upper levels with both ceramic sherds and arrow points. This pattern seems comparable to patterns delineated by morerecent investigations in other areas of the Post Oak Savannah. For instance, investigations of sites both to the northeast at Cooper Lake and south at the Jewett Mine have shown that up to one-third of the projectile points recovered from Late Prehistoric components are dart points, often Gary dart points. These high frequencies have led investigators to postulate that the dart technology was retained well after the introduction of the bow and arrow ca. A.D. 800 (Fields 1995:317). Similar conclusions concerning the retention of dart point technologies were also developed during the Richland Chambers Reservoir investigations (Bruseth et al. 1987:241, 245, 247). This persistence is explained as representing a continued ability to rely on the resource-rich Post Oak Savannah, which formed the basis of hunter-gatherer lifeways. This ability contrasts with the agriculturally based lifeways that developed in the east Texas Piney Woods during the Late Prehistoric period (Bruseth et al. 1987:248-250). As such, settlement 
patterning associated with the Post Oak Savannah cultures should also reflect the retention of hunter-gatherer lifeways.

Archeological surveys associated with the reservoir projects provide information on site types, and site locations provide baseline data for understanding the development of settlement patterns. Data gathered from intensive site testing and mitigation-level excavation enabled investigators at Richland Chambers Reservoir to develop a time-sensitive settlement model that incorporates environmental and demographic factors (Bruseth et al. 1987:250 255). The kinds of information used to develop this model included the presence and absence of site features through time, the size and function of such features, faunal and botanical information from site contexts, regional distributions of nonlocal raw materials, and the kinds of technologies represented at sites. These data suggest that patterns of high residential mobility persisted though the Archaic period, even though human populations were increasing and territory size was decreasing. Persistence of mobility is explained through a concomitant increase in cultural complexity such as the marking of territories with cemeteries and the alleviation of stress through risk sharing (Bruseth et al. 1987:252). However, during the transitional Late Archaic period (A.D. 700-900), a shift to semisedentary settlements with mobile camps only for logistical purposes is postulated. This shift is thought to be due to continued population increase and some environmental degradation. Logistical mobility is seen to continue to increase through the early Late Prehistoric period, associated with almost complete sedentism (Bruseth et al. 1987:254). However, during the latter part of the Late Prehistoric (A.D. 1300-1700), there was a shift back toward a more-mobile pattern similar to that of the transitional Late Archaic period. Investigators concluded that this shift was facilitated by the continued abundant resources of the Post Oak Savannah (Bruseth et al. 1987:249-250).

At the time when the Post Oak Savannah cultures were shifting back to a more-mobile settlement pattern, Caddoan groups in the Piney Woods of east Texas continued their sedentary pattern. Still, there is clear evidence in the form of ceramic and arrow point technologies that, though the Post Oak Savannah and Caddoan cultures may have been economically divergent, interaction between them still occurred. The Caddo were close by and also utilized Post Oak Savannah resources. For instance, Caddo groups are known to have occupied the Neches River drainage, of which Lake Palestine is a part (Perttula 1992). Keith Anderson (1972:141-164), working in the Lake Palestine area, identified a limited early Late Prehistoric period Caddoan manifestation (Alto focus) and a major Caddoan utilization during the latter part of the Late Prehistoric period (Frankston focus); (see Story and Creel [1982:29-30] for a discussion of the chronological usefulness of the Alto and Frankston foci). The Late Prehistoric period sites identified by Anderson include villages or hamlet clusters, small camps, and activity-specific sites.

One reported Caddo hamlet was the Attaway site (41HE114), salvaged in 1975 as it eroded into Lake Palestine (Shafer 1981). The site also contained the remains of a small cemetery. Ceramic vessels and sherds recovered from the hamlet and cemetery include the Late Prehistoric types Maydelle Incised, Bullard Brushed, Killough Pinched, Poynor Engraved, and LaRue Neck Banded. Ceramic sherds of similar style and decoration are known to occur at Richland Chambers Reservoir sites with Late Prehistoric period components (Bruseth et al. 1987:245, 247). Story (1965:253) recovered ceramics from components dating to the latter part of the Late Prehistoric period at Cedar Creek that she considered to be reminiscent of Caddoan ceramic styles associated with the Neches River area.

The prevalence of Caddo ceramics in sites across the Post Oak Savannah certainly indicates that Post Oak Savannah cultures interacted with the Caddo. Yet to be understood, however, is the exact nature and level of this interaction. Evidence also suggests this occurred without overprinting the other lifeways of the Post Oak Savannah cultures (Fields 1995:326 327; Fields et al. 1991; Gadus et al. 2002:18 27). One of the truths that may emerge from Post Oak Savannah archeology is how resilient old patterns were to external influences as long as certain central factors, such as a rich and reliable resource base, remained intact. The retention of old technologies (i.e., the ubiquitous Gary dart point) and the adaptability to work new technologies (ceramics and the bow and arrow) into an old pattern seems to fit well 
with a settlement pattern possibly driven by population dynamics but not limited by environmental change. These patterns argue for a distinct cultural trajectory of the Post Oak Savannah, as first recognized through the investigation of the sites at Cedar Creek Reservoir near the 41HE257 project area (Story 1965).

\section{PREVIOUS INVESTIGATIONS AND TESTING METHODS}

Site 41HE257 was originally recorded in 1983 by TxDOT archeologist Daymond Crawford. At that time, three flakes were noted through surface inspection, but no subsurface excavations were carried out. Still, the site was recommended for test excavations.

In 2002, TxDOT contracted with Archeological and Environmental Consultants, LLC, to conduct an intensive survey to determine the extent of the site within the right of way and to make recommendations for further work. Surface exposures in an area measuring $150 \times 40 \mathrm{~m}$ were scrutinized, and 22 shovel tests $(0.3 \times 0.3 \mathrm{~m})$ were excavated (Figure 2). Ten of the shovel tests produced a total of 16 prehistoric artifacts. These artifacts consist of 1 grog-tempered ceramic sherd, 2 expedient flake tools, and 13 pieces of lithic debitage. They define a site area measuring $103 \mathrm{~m}$ north-south by $29 \mathrm{~m}$ east-west $\left(2,100 \mathrm{~m}^{2}\right)$ along the eastern edge of the right of way. Shovel tests generally produced only 1 artifact; those having higher frequencies (2-3 artifacts) were positioned on the highest part of the site around the large oak tree thicket. These are Shovel Tests 1, 8, 12, and 16 (Perttula and Nelson 2002).

Survey results indicated that the site was shallow and relatively undisturbed. As such, the investigators concluded that the site might represent an intact and discrete occupation that could contain features or interpretable concentrations of artifacts (Perttula and Nelson 2002:5). The site was, therefore, considered to have the potential to contribute to an understanding of Texas prehistory, and further investigations were recommended.

The test excavations at $41 \mathrm{HE} 257$ consisted of hand excavating $14 \mathrm{~m}^{2}\left(4.2 \mathrm{~m}^{3}\right)$ and Gradall stripping $181.5 \mathrm{~m}^{2}$ to search for features in the area of highest artifact frequency. The hand excavations consisted of placing three $2 \times 2-m$ blocks along the north-south axis of the site in the vicinity of shovel tests that produced relatively high artifact frequencies. As such, Block A, the northernmost block, was near Shovel Test 1; Block B was near Shovel Test 16; and Block $\mathrm{C}$ was near Shovel Test 8. Blocks A and B were on the high part of the site at the edges of the dense oak thicket. Block $\mathrm{C}$ was downslope toward the southern edge of the site (Figure 3).

Each block was divided into four $1 \times 1-m$ units that were numbered consecutively across the site. To further define Feature 1, a possible concentration of burned rocks, two more units were placed on the south wall of Block $\mathrm{C}$ for a total of fourteen $1 \times 1-m$ units. Unit and level $(10 \mathrm{~cm})$ were the minimum provenience designation used during test excavations. Vertical provenience was maintained within each block by a level line set $10 \mathrm{~cm}$ above the highest surface point at the block edge. Excavations generally proceeded to 40 or $50 \mathrm{~cm}$ below these level lines, or approximately $30-40 \mathrm{~cm}$ below the ground surface. Excavation was stopped once firm red clay was encountered.

All artifacts recovered from the $1 / 4$-inch screening of unit and level soils were bagged, with their appropriate provenience designation, and returned to the Austin office. Artifact counts by unit and level were recorded in the field as a means of tracking changes in artifact frequencies across the site. Notes concerning soil color and texture, disturbances, and any possible cultural features also were kept by block. Two wall profiles of each block were photographed using black-and-white print and color slide film. Designated features were further recorded using a standardized feature form, and features were photographed and drawn in both plan and profile views as appropriate.

As the block excavations drew to a close, Gradall stripping was undertaken using a machine and operator provided by TxDOT. Stripping was carried out to explore for more features. Four areas surrounding the central oak thicket were stripped. The area in the north covered $15 \times 3 \mathrm{~m}$, and the south area was $10.0 \times 1.5 \mathrm{~m}$; the long axis of both was oriented east to west. The stripped area on the east side of the site was $19 \times 3 \mathrm{~m}$, and on the west, $21 \times 3 \mathrm{~m}$. These areas were oriented north to south. All four areas were shovel-skimmed to delineate possible features, but only two possible postholes were defined (see feature descriptions below). 


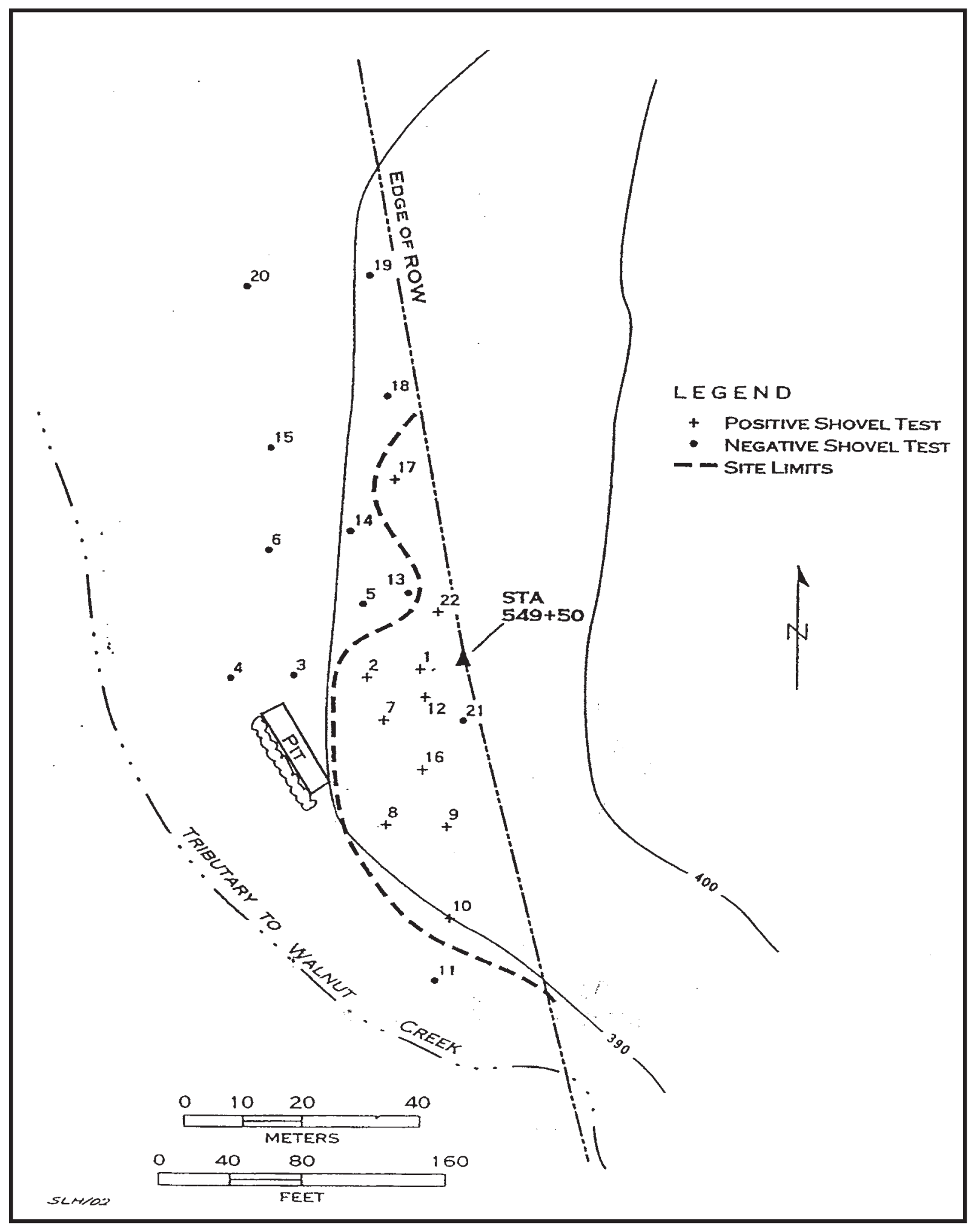

Figure 2. Plan of 41HE257 showing 2002 shovel test excavations (from Perttula and Nelson 2002). 


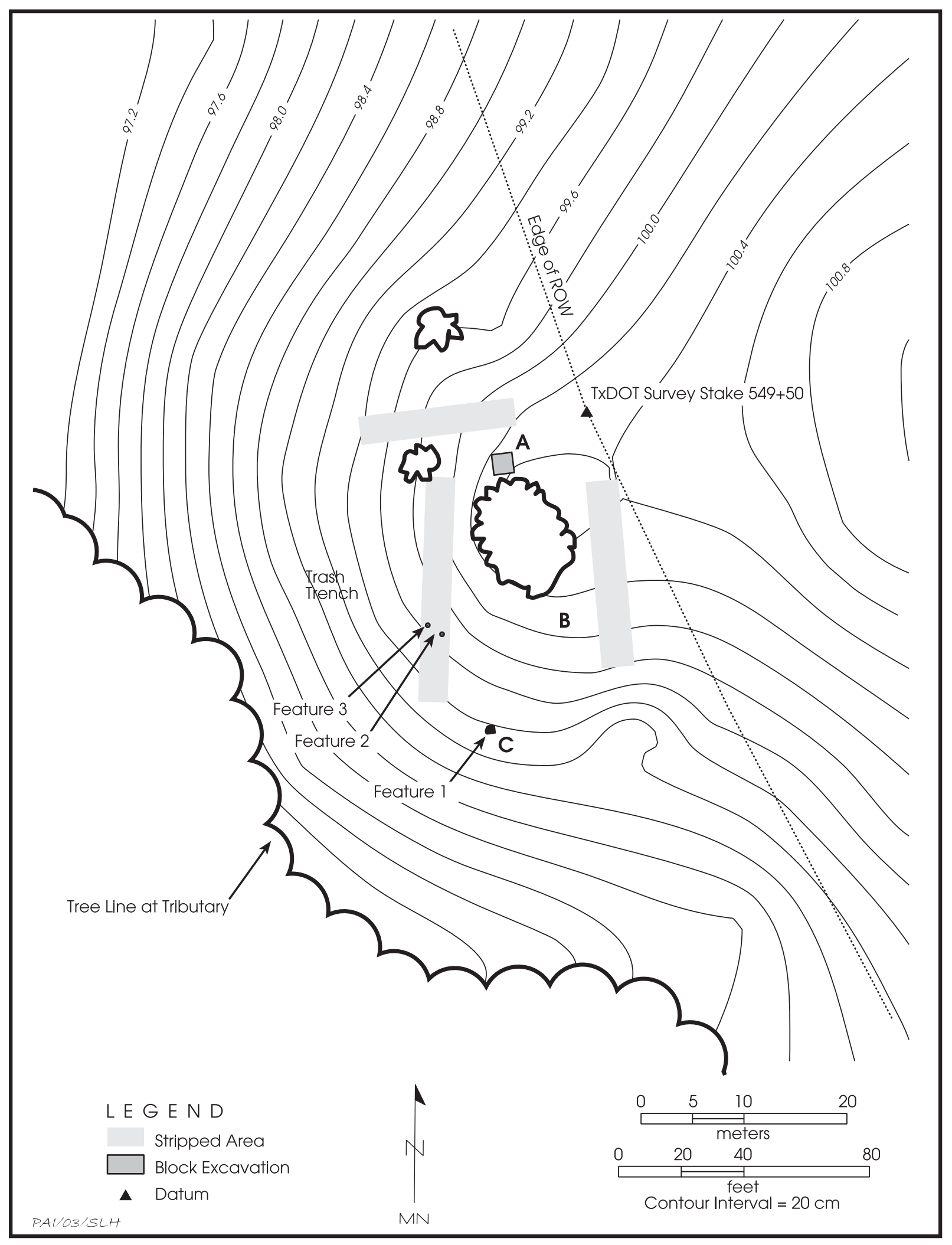

Figure 3. Topographic map of 41HE257 showing 2003 test excavations. 
Finally, a map showing the topography, excavations, and other surface features was constructed using a transit and stadia rod. At the same time, two datum stakes were established. One datum was located near TxDOT survey stake 549+50, and another was placed at the edge of the oak thicket near the west side of Block B (see Figure 3).

The materials recovered from 41HE257 were returned to Austin for laboratory processing. Artifacts were washed and then labeled with the site number and a lot number indicating provenience. All specimens identified as tools were given a lot-specific specimen number to aid in their analysis. Other remains such as charcoal, petrified wood, and ironstone were cleaned and then counted or weighed by provenience. Each artifact or item class was recorded in a specimen inventory catalog.

The focus of the analysis of the recovered cultural materials is to characterize the collection in terms of the possible periods of occupation represented and to relate the materials to possible aspects of site use and function. Given the probably mixed nature of the deposits, no attempt was made to relate functional inferences to specific periods of occupation. Rather, these inferences provide an overall determination of site function. Attributes recorded for chipped stone materials are artifact type, tool type, and raw material. Attributes recorded for ceramic vessel sherds are temper, body part, and decoration. Where possible, both lithic tools and ceramic sherds are related to established temporally diagnostic types based on the work of Turner and Hester (1999) and Suhm and Jelks (1962).

All artifacts, field journals, artifact inventories, test unit and trench notes, site maps, profile drawings, sediment descriptions, analysis notes, and photographs generated during the project are curated at the Texas Archeological Research Laboratory, The University of Texas at Austin.

\section{TESTING RESULTS}

Test excavations at 41HE257 indicate that the part of the site within the TxDOT right of way is indeed shallow, with 30-40-cm-thick loamy sediments. Three features were defined. These features consist of a concentration of possible burned ironstone found at the base of Block $\mathrm{C}$ and two possible postholes in the western stripped area. Upon investigation, the possible postholes were found to be roots or rodent runs rather than cultural features; the origin of the possible burned rock concentration could not be determined with certainty. Artifacts were recovered in low frequencies and consist of seven lithic tools, lithic debitage, several lithic cores, and ceramic sherds. One piece of purple container glass also was recovered. No prehistoric faunal materials were recovered, and macrobotanical remains were extremely limited. Two (of three) radiocarbon assays indicate that much of the limited macrobotanical sample likely is of recent origin.

Disturbances to the site were found to be more prevalent than the survey results indicated. Evidence of root and rodent disturbance within the excavations was extensive. These disturbances likely account for a rodent mandible found in Level 1 and a piece of container glass found in Level 4 of Block A. Trees on the site, though making up only about 15 percent of the ground cover, are large cedars or hardwoods. A large pit on the west edge of the site excavated by the landowner for garbage disposal has been recently expanded. The landowner has developed the area ca. 50 to $70 \mathrm{~m}$ east of the investigation area as a primary residence with a gravel access road and drainage to an adjacent tank and earthen dam. This development has likely disturbed any upslope portion of the site that may have existed east of the TxDOT right of way.

\section{Sediments and Stratigraphy}

Sediments revealed by the excavations are similar in color and texture to those described for Woodtell soils as mapped for the area by Hatherly and Mays (1979). Site soils have a loamy surface layer that is $30-40 \mathrm{~cm}$ thick and that contains moderate amounts of siliceous material, petrified wood, and ironstone gravel. Small areas of gravelly soils have been previously recorded within the Woodtell soils (Hatherly and Mays 1979:36). The slightly greater thickness of the surface layer at the site may be because the site retains sediments eroding off the uplands. Excavations and machine stripping stopped at a mottled red clay encountered below the surface layer that corresponds to the subsurface layer of the Woodtell soil description (Hatherly and Mays 1979:36). The red clay is a Bt horizon developed in the Eocene 
bedrock, while the overlying sands likely are Holocene colluvium.

\section{Features}

Feature 1 is a concentration of possibly burned ironstone rocks (ferruginous sandstone) (Figure 4). The northernmost edge of the feature was encountered in Unit 12 of Block C, and a few outlying rocks were found in Units 10 and 11. Two more 1x1-m units, Units 13 and 14, were opened along the south wall of Units 11 and 12 to further define the feature. When these additional units were completed, the main concentration of rocks was found to occur across Unit 14 (see Figure 4a). The feature appeared to be composed of two arcs of stones centered on a cluster of stones in the southeast corner of Unit 14. If the arcs are extended beyond the units, it appears that only a fourth of the feature was exposed in the block. The feature extended vertically from 30 to $39 \mathrm{~cm}$ below the surface, with most rocks positioned 1-2 $\mathrm{cm}$ above the basal clay and following the natural slope of the clay to the southeast. Rocks within the arcs ranged from 2 to $35 \mathrm{~cm}$ across. In all, 176 ironstone rocks $(38.7 \mathrm{~kg})$ and 24 quartzite gravels $(1.75 \mathrm{~kg})$ were removed from the exposed part of the feature. None of the quartzite gravels appeared to be worked.

Whether the ironstone rocks of the feature are burned and, therefore, indicate that the feature constitutes the remains of a hearth, could not be answered unequivocally. Ironstone rock derives from the Eocene bedrock and commonly crops out on eroded hilltops and slopes within the area. Given its natural reddish coloration and friable nature, it is often difficult to determine when ironstone has been burned through usage as a hearth stone. Characteristics that have been used to define burned ironstone are thermoremnant magnetism, as evidenced by the deflection of a compass needle, angular fracturing, surface cracking or crazing, an oxidized reddish or blackish color, and a friable surface texture (Fields et al. 1991:80).

The ironstone rocks from Feature 1 did not show thermoremnant magnetism, nor were they particularly oxidized or angularly fractured, cracked, or crazed. Many appeared to have a friable surface, but this characteristic could result from natural weathering. Neither did the quartzite gravels from the feature appear to be fractured, cracked, crazed, or potliddedsuggesting they are not burned. Consequently, the rocks from the feature do not provide definitive information as to the nature of Feature 1. Only the semicircular appearance of the rock concentration suggests a hearth.

Other characteristics may provide some help in interpreting the feature. No signs of discoloration from burning of the underlying clay or loamy surrounding fill were observed. There was a light gray ovoid stain with a diameter of $50 \mathrm{~cm}$ below the rocks at the eastern end of the outermost arc of stones. After the stones were removed, the stain was excavated to reveal a 2-3-cm-deep basin that quickly tapered to $15 \mathrm{~cm}$ in diameter toward its southwest edge (see Figure $4 \mathrm{~b}$ ). The overall depth of the stain from the base of Level 5 was $24 \mathrm{~cm}$. Bits of decomposing root were observed within the stain. These characteristics suggest that the stain was the remains of a large tree root or animal burrow.

A sample of wood charcoal (8.4 g) was recovered from screening the fill of Unit 12, Level 4, above the stain, and one small sample $(0.3 \mathrm{~g})$ was found in situ within the stain. The placement of these charcoal samples within and just above a root or rodent disturbance calls into question their utility in interpreting Feature 1 as a hearth, but the sample from Unit 12, Level 4 , was used to obtain a radiocarbon assay. That assay produced a calibrated two-sigma date range of A.D. 785-1019 (Table 1). Yet, since this sample is not unequivocally associated with the feature, it does little to help determine the origin of the feature.

Features 2 and 3 were first defined as possible postholes in plan view, but after cross sectioning, they were found to be shallow and amorphous in outline, suggesting that they are root or rodent impressions. These features were situated within $0.5 \mathrm{~m}$ of each other at the south end of the west stripped area. Feature 2 was $20 \mathrm{~cm}$ in diameter in plan and $6 \mathrm{~cm}$ deep. It contained a dark brown sandy loam with charcoal flecking. Feature 3 was $12 \mathrm{~cm}$ in diameter and $3 \mathrm{~cm}$ deep. It contained a brown sandy loam. Screening this feature fill did not produce any cultural materials.

\section{Radiocarbon Assays}

Three radiocarbon samples were sent to the 


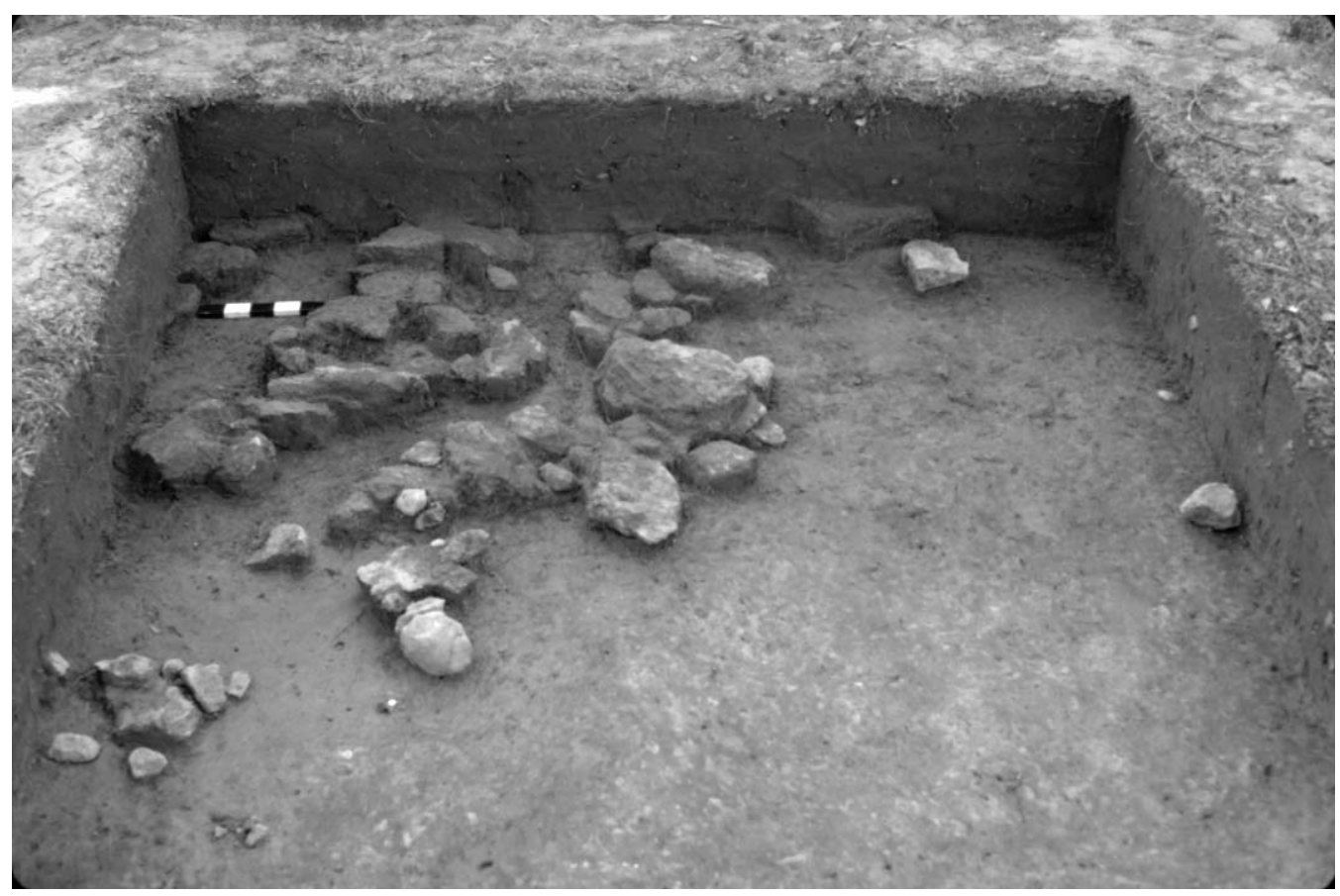

a

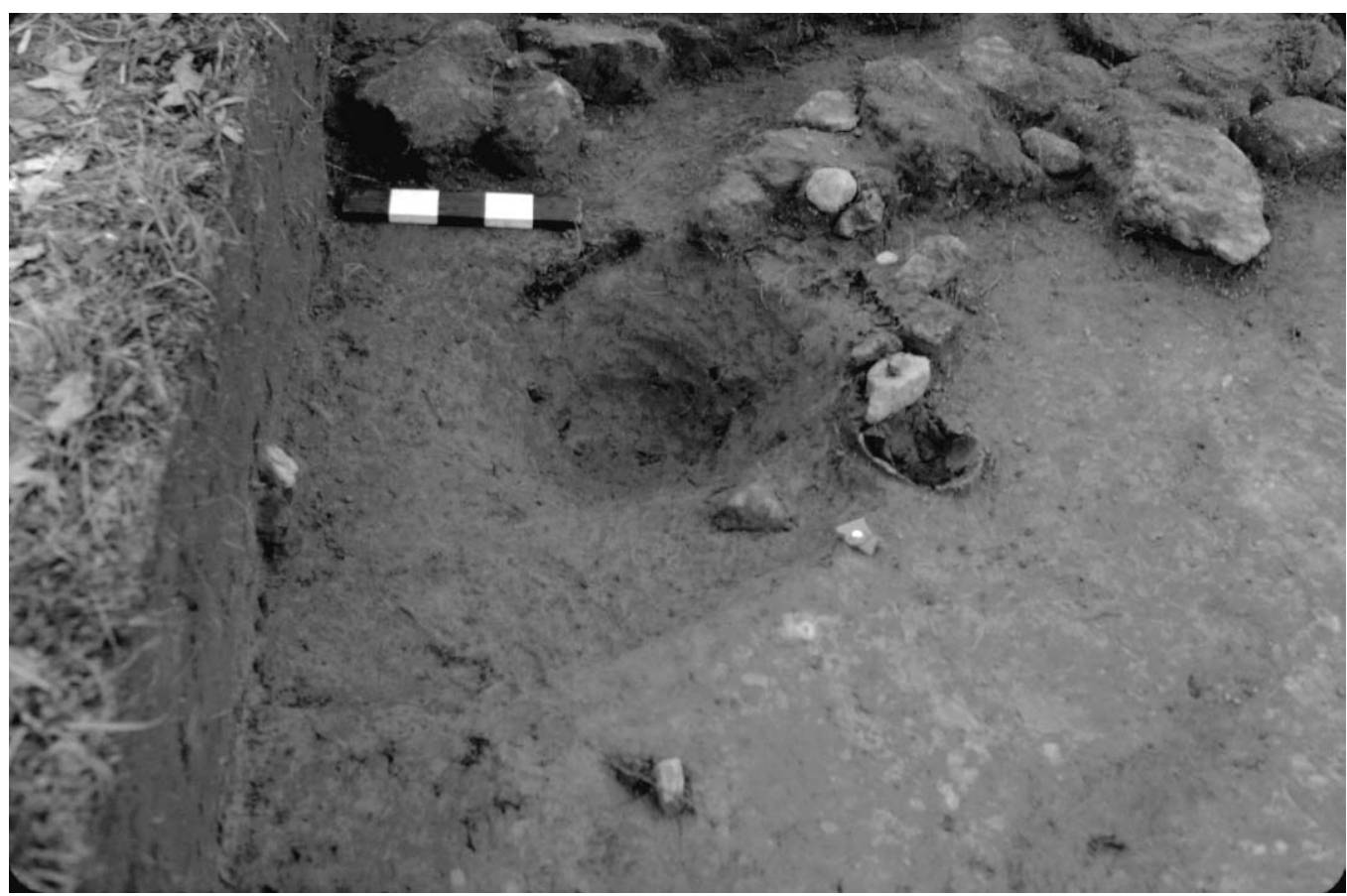

Figure 4. Photographs of Feature 1. (a) Concentration of ironstone in Units 12-15; (b) post-excavation view of light gray stain below the outer arc of stones in Unit 12 . 
Table 1. Radiocarbon assays from $41 \mathrm{HE} 257$

\begin{tabular}{l|l|c|c|c}
\hline $\begin{array}{l}\text { UGA Sample } \\
\text { Number }\end{array}$ & Provenience & $\begin{array}{c}\text { Radiocarbon Age } \\
\text { (B.P. } \pm 1 \text { sigma) }\end{array}$ & $\begin{array}{c}\text { Corrected Age } \\
\text { (B.P. } \pm 1 \text { sigma) }\end{array}$ & $\delta^{13} \mathrm{C}$ \\
\hline 12271 & Unit 2, Level 3 & $70 \pm 40$ & $40 \pm 40$ & -27.00 \\
\hline 12272 & Unit 8, Level 3 & $80 \pm 40$ & $90 \pm 40$ & -24.57 \\
\hline 12273 & Unit 12, Level 4 & $1,180 \pm 40$ & $1,100 \pm 40$ & -30.20 \\
\hline
\end{tabular}

University of Georgia's Center for Applied Isotope Studies for dating. Two of the assays were run on wood charcoal from Block A, Unit 2, and Block B, Unit 8. Both samples came from Level 3 at 20 to $30 \mathrm{~cm}$ below the surface. These charcoal samples were recovered from the 1/4-inch screening process. Both of these assays yielded modern ages (see Table 1). As noted above, the third assay was on wood charcoal recovered from the screen in Block C, Unit 12, Level 4 (30$40 \mathrm{~cm}$ below the surface); the sample came from sediment just above Feature 1. This assay produced a calibrated one-sigma date range of A.D. 894-993 with intercepts at A.D. 904, 910, 976 and a two-sigma date range of A.D. 785-1019 with intercepts at A.D. 904, 910, and 976. The calibration was completed using a revised CALIB 3.0 program and data sets from Struiver et al. 1998. Calibrated results suggest that the site has an early Late Prehistoric component (A.D. 900-1300).

\section{ARTIFACTS AND OTHER MATERIALS}

Artifacts recovered from 41HE257 consist of 26 ceramic sherds, 2 arrow points, 1 dart point, 1 drill base, 3 utilized flakes, 204 pieces of lithic debitage, 6 cores, and 1 ground stone fragment. Also, 1,009 pieces of petrified wood, 88 ironstone fragments $(4,018 \mathrm{~g})$, and 169 quartzite gravels $(8,961 \mathrm{~g})$ were recorded from the excavation units (Table 2). These rock totals include only those tallied from unit and level provenience. An additional 176 ironstone rocks
$(38.7 \mathrm{~kg})$ and 24 quartzite pebbles $(1.75 \mathrm{~kg})$ made up Feature 1.

Macrobotanical materials are limited (total recovery is $12.3 \mathrm{~g}$ ) and consist of what appears to be wood charcoal. The two samples possibly associated with Feature 1 came from the fill of Unit 12, Level 4 (8.4 g), and one small in situ sample $(0.3 \mathrm{~g})$ from the same unit and level. Unit 12 also produced a small sample $(<0.1 \mathrm{~g})$ from Level 3, and a sample $(0.7 \mathrm{~g})$ was recovered from Unit 13, Level 2. Block A produced a sample $(2.6 \mathrm{~g})$ from Unit 2 , Level 3 , and a sample $(0.3 \mathrm{~g})$ came from Block B, Unit 8, Level 3. Radiocarbon dates suggest that much of this charcoal is of modern age.

No faunal materials associated with the prehistoric occupation of the site were recovered. One fragment of a rodent mandible was recovered from Block A, Unit 3, Level 1, but the mandible's good state of preservation and the number of burrows noted in the excavation suggest that this bone is modern.

A single piece of purple container glass was recovered from Block A, Unit 4, Level 4. The glass came from just above the red clay at $44 \mathrm{~cm}$ below the surface. The presence of this historic artifact deep within the site attests to the bioturbation that has occurred.

\section{Ceramics}

The 26 ceramic sherds recovered are generally small-ca. 1 to $5 \mathrm{~cm}$ across - and most have eroded surfaces probably resulting from the highly acidic soils. Twenty-one are undecorated

Table 2. Materials recovered from 41HE257

\begin{tabular}{|c|c|c|c|c|c|c|c|c|c|}
\hline \multirow[b]{2}{*}{ Block } & \multirow{2}{*}{$\begin{array}{l}\text { Lithic } \\
\text { Tools }\end{array}$} & \multirow[b]{2}{*}{ Cores } & \multirow[b]{2}{*}{ Debitage } & \multirow[b]{2}{*}{ Ceramics } & \multirow{2}{*}{$\begin{array}{l}\text { Petrified } \\
\text { Wood }\end{array}$} & \multicolumn{2}{|c|}{ Ironstone } & \multicolumn{2}{|c|}{ Quartzite } \\
\hline & & & & & & No. & Wt. (g) & No. & Wt. (g) \\
\hline A & 0 & 1 & 73 & 9 & 53 & 20 & 723.3 & 21 & 839.1 \\
\hline B & 1 & 3 & 48 & 16 & 200 & 14 & 530.8 & 46 & $2,624.6$ \\
\hline $\mathrm{C}$ & 6 & 2 & 83 & 1 & 756 & 54 & $2,764.2$ & 102 & $5,498.0$ \\
\hline Totals & 7 & 6 & 204 & 26 & 1,009 & 88 & $4,018.3$ & 169 & $8,961.7$ \\
\hline
\end{tabular}

Note: This excludes ironstone and quartzite from Feature 1. 
body sherds, 1 is a body sherd with exterior surface decoration, and 4 are undecorated rim sherds. The decoration observed consists of linear incising. One carinated rim with a rounded lip was recovered (Figure 5), and the other three rims are too small to determine rim orientation, though they also have rounded lips. The carinated rim is tempered with grog and bone, and the three indeterminate rims are tempered with grog and bone, grog, and bone. The incised body sherd is bone tempered. Within this small collection, grog temper is found in 12 sherds (46 percent), grog and bone in 9 sherds ( 35 percent), and bone in 4 sherds (15 percent); in 1 sherd (4 percent), temper could not be determined.

\section{Chipped Stone Tools}

The three projectile points recovered came from Block $\mathrm{C}$ in the southern part of the site. Single Scallorn and Catahoula arrow points were recovered from Level $2(10-20 \mathrm{~cm}$ below the surface) in Units 13 and 14, respectively. Both were fashioned from fine-grained quartzite. The Catahoula arrow point is missing its distal end, one barb, and one stem corner (see Figure 5). It is slightly serrated and is $0.35 \mathrm{~cm}$ thick. The Scallorn arrow point is mostly complete and is missing only one corner of its stem (see Figure 5). The point is also well serrated. It is $2.25 \mathrm{~cm}$ long, $1.54 \mathrm{~cm}$ wide, and $0.29 \mathrm{~cm}$ thick, with a neck width of $0.54 \mathrm{~cm}$ and a blade length of $1.96 \mathrm{~cm}$. The presence of these two points suggests an early Late Prehistoric or early Caddoan period occupation of the site (Fields et al. 1997:43-51; Thurmond 1990:226227; Turner and Hester 1999). The single prehistoric radiocarbon date from the site, which was on charcoal from two levels below the recovery level of these points, corresponds well with the beginning of the early Late Prehistoric period. The third point-a single Gary dart point fashioned from fine-grained quartzite-was recovered from Unit 14, Level 3 (20-30 cm below the surface). This point is missing its distal end; its width is $2.25 \mathrm{~cm}$, thickness is $0.79 \mathrm{~cm}$, and base length is $1.75 \mathrm{~cm}$ (see Figure 5). Gary dart points are ubiquitous in Late Archaic and Late Prehistoric period contexts. They are known to occur with arrow points in early Caddoan components of northeast Texas (Fields et al. 1997:43-47), but this specimen's presence below the arrow points could suggest that it is associated with an earlier occupation.

One drill base was recovered from Unit 7, Level 3 (20-30 cm below the surface). The bifacially worked shaft of this drill is broken just below the base and along one basal edge. The intact basal edges are ground, likely to facilitate hafting. The width of the drill shaft at its juncture with the base is $0.76 \mathrm{~cm}$, and base thickness is $0.40 \mathrm{~cm}$. This drill was fashioned from quartzite and is similar in form to the awl/ drill described for Late Prehistoric period sites at the Richland Chambers Reservoir (Irvine and McGregor 1987:112).

Three utilized flakes were also discovered among the lithic debitage, as all debitage was examined under 10x magnification for evidence

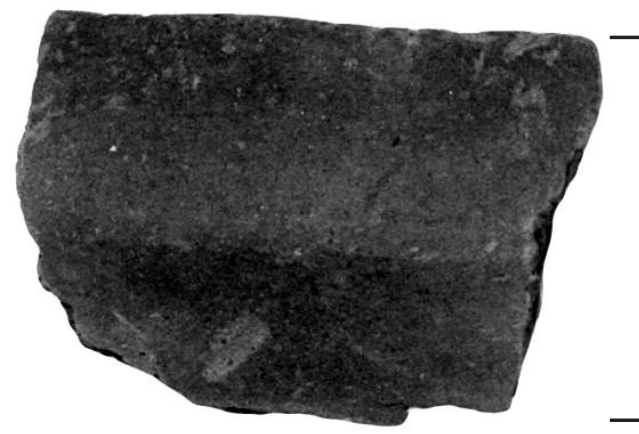

Rim Sherd
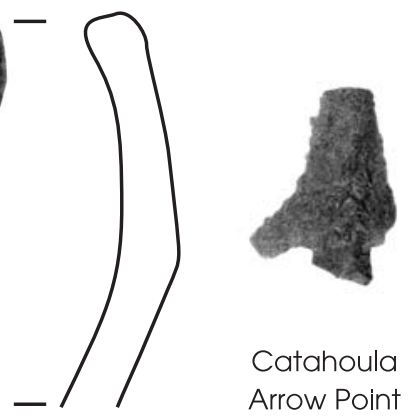

Catahoula Arrow Point

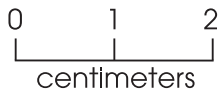

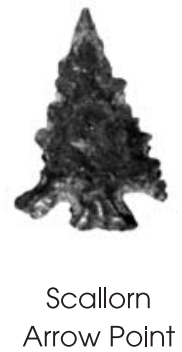

Arrow Point

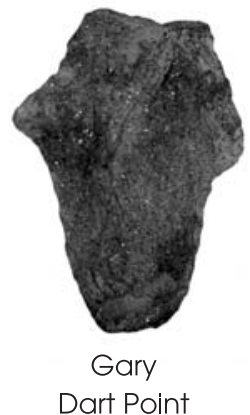

Dart Point

Figure 5. A carinated rim sherd and projectile points from 41HE257. 
of use. These flakes are complete, proximal, or medial fragments with one or two utilized edges. Flake size is ca. $2 \mathrm{~cm}$ in diameter, and all three flakes are chert. The flakes were recovered from Block C, Unit 9, Levels 1 and 3 (0-10 and 20$30 \mathrm{~cm}$ below the surface), as well as from Unit 14, Level 3.

\section{Lithic Debitage, Cores, and Ground Stone}

The lithic debitage is mainly small medial and distal flake fragments. It appears that this collection represents mostly tool manufacture from small cobbles and probably some tool refurbishing. Raw materials observed within the debitage sample are quartzite $(n=181,89$ percent), chert ( $\mathrm{n}=14,7$ percent), and petrified $\operatorname{wood}(n=9,4$ percent).

Most of the cores recovered are also quartzite $(\mathrm{n}=4)$, though two are petrified wood. These cores display one to four multidirectional flake removals. Cores were recovered from all three blocks; Block B produced the most cores at three, though it produced the least debitage at 49 flakes.

The single ground stone fragment is a $3-\mathrm{cm}$ diameter tabular ironstone fragment that displays polish on one flat surface. It is $0.72 \mathrm{~cm}$ thick. The fragment was recovered from Block B, Unit 6, Level 2.

\section{Chipped Stone Raw Materials}

As noted, quartzite constitutes the overwhelming portion of the chipped stone tools and debitage. Fifty-seven percent of the tools and 89 percent of the lithic debitage is quartzite. Quartzite cobbles were likely available to the site occupants in local Uvalde Gravel deposits found in knoll-top soils associated with the
Eocene Wilcox Formation. Small quantities of chert cobbles could also be found in this gravel.

Distinctive within the sample is one utilized flake of Pisgah Ridge chert recovered from Unit 14, Level 3 (20-30 cm below the surface). This chert has a speckled appearance due to numerous fossil inclusions. The only known source of the chert-an outcrop within the Tehuacana Limestone near the town of Richland in Navarro County-is close to Richland Chambers Reservoir. Tools and debitage of this chert are found at sites in the Richland Chambers Reservoir area, within the middle Trinity basin, and as far east as Lake Palestine on the upper Neches River (McGregor 1987b:189-192). Use of this chert in the Richland Chambers Reservoir area decreased from the Late Archaic period through the Late Prehistoric period. Investigators interpreted this decline as a marker of decreased group territory size (McGregor 1987b:191-192).

\section{DISTRIBUTIONS}

The vertical distribution of debitage by level across all three excavation blocks indicates that most came from Levels 2 and 3, 10-30 cm below the surface (Table 3). The ceramics follow a similar pattern, though they have closer percentages through the first three levels. Both arrow points were recovered from Level 2 , and a single utilized flake was recovered from Level 1 . The Gary dart point, the drill base, and two utilized flakes were recovered from Level 3. Thus, Levels 2 and 3 encompass most of the occupational debris at the site, although it remains unclear as to the number of components represented by this deposit.

The distribution of ironstone and quartzite pebbles in the blocks do not follow the pattern of the debitage or sherds (Table 4). The weights for both kinds of stones generally increase with

Table 3. Distribution of debitage and ceramics at $41 \mathrm{HE257}$

\begin{tabular}{c|cc|cc|cc|cc}
\hline \multirow{2}{*}{ Level } & \multicolumn{2}{|c|}{ Block A } & \multicolumn{2}{c|}{ Block B } & \multicolumn{2}{c|}{ Block C } & \multicolumn{2}{c}{ Units 13\& 14 } \\
\cline { 2 - 9 } & Debitage & Ceramics & Debitage & Ceramics & Debitage & Ceramics & Debitage & Ceramics \\
\hline 1 & 6 & 2 & 3 & 5 & 3 & 0 & - & - \\
2 & 21 & 3 & 15 & 3 & 28 & 1 & 9 & 0 \\
3 & 45 & 4 & 10 & 5 & 16 & 0 & 7 & 0 \\
4 & 1 & 0 & 20 & 3 & 5 & 0 & 5 & 0 \\
5 & - & - & - & - & - & - & 2 & 0 \\
\hline Totals & 73 & 9 & 48 & 16 & 52 & 1 & 23 & 0 \\
\hline
\end{tabular}


Table 4. Distribution of ironstone and quartzite pebbles at $41 \mathrm{HE257}$

\begin{tabular}{c|cc|cc|cc|cr}
\hline \multirow{2}{*}{ Level } & \multicolumn{2}{|c|}{ Block A* } & \multicolumn{2}{c|}{ Block B } & \multicolumn{2}{c|}{ Block C } & \multicolumn{2}{c}{ Units 13 \& 14 } \\
\cline { 2 - 9 } & Ironstone & Quartzite & Ironstone & Quartzite & Ironstone & Quartzite & Ironstone & Quartzite \\
\hline 1 & - & - & 0.0 & 78.5 & 0.0 & 0.0 & - & - \\
2 & - & - & 126.3 & 713.8 & 508.6 & 499.8 & 0.0 & 336.8 \\
3 & - & - & 194.3 & 761.1 & 337.9 & $1,323.9$ & 56.5 & 323.6 \\
$4^{* *}$ & - & - & 210.2 & $1,071.2$ & $1,861.2$ & $2,439.9$ & 0.0 & 184.9 \\
$5^{* *}$ & - & - & - & - & - & - & 0.0 & 389.3 \\
\hline Totals & 723.3 & 839.1 & 530.8 & $2,624.6$ & $2,707.7$ & $4,263.6$ & 56.5 & $1,234.6$ \\
\hline
\end{tabular}

Note: All weights are in grams.

* Because of a processing error, ironstone and quartzite weights were not recorded by level for Block A.

** Feature 1 occurs in Levels 4 and 5 of Units 13 and 14 and contained $38.7 \mathrm{~kg}$ of ironstone and $1.75 \mathrm{~kg}$ of quartzite.

depth rather than peaking at Levels 2 or 3 . This suggests that, though some of these (especially ironstone) may have been used as hearth stones, there also is a substantial natural occurrence of these stones at the site. The pattern of ironstone and quartzite is clearest in Blocks B and $\mathrm{C}$ (see Table 4). The large amounts of ironstone $(38.7 \mathrm{~kg})$ and quartzite $(1.75 \mathrm{~kg})$ recovered from Feature 1 in Levels 4 and 5 of Units 13 and 14 skew the distribution pattern in those units, but the vertical separation of Feature 1 from the main artifact distribution peak within Levels 2 and 3 may suggest that the feature is not associated with the main component represented by that peak. This is one more bit of evidence that points to a possible natural origin for the feature.

There are a few differences in horizontal artifact distributions across the site. For instance, most of the ceramic sherds $(n=25)$ came from Blocks A and B, with more than half $(\mathrm{n}=16$, 61 percent) from Block $B$. One sherd came from Block $\mathrm{C}$, and all three projectile points came from Block C, Unit 13. These differences could be suggestive of differential use of space at the site, but it is difficult to attach much significance to them given that the excavation units were clustered in just three areas.

\section{ASSESSMENT AND RECOMMENDATIONS}

The results of test excavations at 41HE257 suggest that the site was likely a small limitedpurpose camp probably associated with hunting activities. This suggestion is based on what the site lacks (i.e., features), the low artifact density, and its position in the upland near a headwater tributary of Walnut Creek. Occupa- tional features such as hearths, postholes, and refuse or storage pits are expected and have been found at sites identified as base camps or semisedentary hamlets in the middle Trinity River basin (Bruseth et al. 1987:240-247) and at sites within the major drainages associated with the Cedar Creek and Lake Palestine areas (Shafer 1981; Story 1965). These kinds of features were not discovered at 41HE257, even though $181.5 \mathrm{~m}^{2}$ of the site area that produced the highest artifact frequencies were mechanically stripped.

Two of the three features that were defined at the site were found to be root or rodent disturbances. The third, Feature 1, is a circular concentration of ironstone that cannot be defined unequivocally as a hearth because the rocks associated with the feature may not be burned. There are ironstone outcrops in the area, and the feature may be a natural concentration at the top of the Bt horizon.

Other kinds of materials needed to make unequivocal interpretations concerning the site are also limited or lacking. Tool recovery consists of only eight items: three projectile points, one drill, three utilized flakes, and a ground stone fragment. This suggests a recovery rate of 1.9 tools per cubic meter. Such a low recovery rate would make it difficult to extract an interpretable tool sample from the site, given the small area remaining within the TxDOT right of way. Also, the paucity of macrobotanical materials (much of which appears to be modern based on radiocarbon analysis) and lack of faunal remains indicate that the site cannot contribute subsistence information.

The single radiocarbon assay that proved to be prehistoric in age provides the strongest 
evidence for chronological placement. That date, calibrated to A.D. 785-1019 (a two-sigma date range), indicates that 41HE257 has an early Late Prehistoric period component. All of the diagnostic lithic artifacts recovered, i.e., the Gary dart point and the Scallorn and Catahoula arrow points, could be associated with this date. As noted in the Archeological Background section of this report, Gary dart points are common in Late Prehistoric period components and may indicate that Late Archaic hunting technology survived long after bow and arrow technology was introduced (Fields et al. 1997:45-47). As such, the Gary point recovered from 41HE257 would not be unusual in an early Late Prehistoric component.

Most sherds in the testing sample are undecorated and, therefore, difficult to attribute to a specific time period. Overall, these ceramic sherds do not appear dissimilar to Caddo ceramics found to the east in the upper Neches River drainage. The single carinated rim sherd and the linear incised sherd in the sample would not be out of place in either early or late Late Prehistoric components. The linear decoration found on one sherd could be associated with early Caddoan ceramic types such as Kiam Incised or Canton Incised as well as the later Frankston focus type Maydelle Incised (Suhm and Jelks 1962). The grog and bone tempering of these sherds can also be indicative of ceramic vessels from both periods.

Two other bits of evidence support the definition of an early Late Prehistoric component rather than Late Archaic or later Late Prehistoric components. These are the recovery of a drill fragment and the single utilized flake of Pisgah Ridge chert. The use of drills is thought to have begun in the early Late Prehistoric, though it continued through the entire Late Prehistoric period (Bruseth et al. 1987:242, 245). Pisgah Ridge chert in Henderson County is rela- tively far from its source. Use of this chert is known to have decreased in extent during the Late Prehistoric period-a fact used by investigators at Richland Chambers to propose decreased territory size (McGregor 1987b:191-192). The presence of this chert at 41HE257 far from its source may indicate that it is representative of an early Late Prehistoric component rather than a later component.

Given all the evidence, however, the identification and isolation of discrete components at 41HE257 remains highly questionable. The thinness of the deposit (ca. $40 \mathrm{~cm}$ ), the evidence for mixing, the scarceness of datable materials, and the limited artifact recovery indicate that unequivocal definition of site components is not possible.

One potentially interesting aspect of 41HE257 is its location in the Post Oak Savannah between the Trinity and Neches River basins, given the occasional use of the area by Neches River Caddo groups and extensive evidence from other investigations concerning indigenous Post Oak Savannah groups who retained a unique orientation to this resource-rich area. However, the test excavations at 41HE257 have shown that the kinds of information that would enable investigators to press questions concerning subsistence, group interaction and affiliation, and most specifically chronological placement are not present at the site. Consequently, further study of this site would not add significantly to what is already presented in this report, nor would it further the understanding of Texas prehistory. Because the site lacks important information, it is ineligible for listing in the National Register of Historic Places or designation as a State Archeological Landmark. As such, the transportation activity associated with this site should be allowed to proceed without additional archeological investigations. 


\section{REFERENCES CITED}

Anderson, Keith M.

1972 Prehistoric Settlement of the Upper Neches River. Bulletin of the Texas Archeological Society 43:121-198.

Bruseth, James E., Daniel E. McGregor, and William A. Martin

1987 Hunter-Gatherers of the Prairie Margin: Summary of the Prehistoric Archaeological Record. In Hunter-Gatherer Adaptations along the Prairie Margin: Site Excavations and Synthesis of Prehistoric Archaeology, edited by Daniel E. McGregor and James E. Bruseth, pp. 229256. Richland Creek Technical Series, Volume III. Archaeology Research Program, Institute for the Study of Earth and Man, Southern Methodist University, Dallas.

Bureau of Economic Geology

1965 Geologic Atlas of Texas, Tyler Sheet. Bureau of Economic Geology, The University of Texas at Austin.

1972 Geologic Atlas of Texas, Dallas Sheet. Bureau of Economic Geology, The University of Texas at Austin.

Correll, Donovan S., and Marshall C. Johnston

1979 Manual of the Vascular Plants of Texas. The University of Texas at Dallas, Richardson.

Fields, Ross C., Marie E. Blake, and Karl W. Kibler 1997 Synthesis of the Prehistoric and Historic Archeology of Cooper Lake, Delta and Hopkins Counties, Texas. Reports of Investigations No. 104. Prewitt and Associates, Inc., Austin.

Fields, Ross C.

1995 The Archeology of the Post Oak Savannah of East Central Texas. Bulletin of the Texas Archeological Society 66:301-330.

Fields, Ross C., L. Wayne Klement, C. Britt Bousman, Steve A. Tomka, Eloise F. Gadus, and Margaret A. Howard

1991 Excavations at the Bottoms, Rena Branch, and Moccasin Springs Sites, Jewett Mine Project, Freestone and Leon Counties, Texas. Reports of Investigations No. 82. Prewitt and Associates, Inc., Austin.

Gadus, E. Frances, Jennifer K. McWilliams, and Ross C. Fields

2002 Data Recovery Excavations at the McGuire's Garden Site (41FT425), Jewett Mine, Freestone County, Texas. Reports of Investigations No. 134. Prewitt and Associates, Inc., Austin.

Hatherly, Don T., and Major D. Mays

1979 Soil Survey of Henderson County, Texas. U.S. Department of Agriculture, Soil and Conservation Service, in cooperation with the Texas Agricultural Experiment Station.

Irvine, Marilee, and Daniel E. McGregor

1987 Excavations at 41NV173, the Little Cedar Creek Site. In Hunter-Gatherer Adaptations along the Prairie Margin: Site Excavations and Synthesis of Prehistoric Archaeology, edited by Daniel E. McGregor and James E. Bruseth, pp. 97-123. Richland Creek Technical Series, Volume III. Archaeology Research Program, Institute for the Study of Earth and Man, Southern Methodist University, Dallas.

McGregor, Daniel E.

1987a Prehistoric Research Background. In Introduction to the Richland Creek Archaeological Project: Environmental Background and Cultural Setting, edited by James E. Bruseth and Randall W. Moir, pp. 11-19. Richland Creek Technical Series, Volume I. Archaeology Research Program, Institute for the Study of Earth and Man, Southern Methodist University, Dallas.

1987b Lithic Raw Material Utilization. In Hunter-Gatherer Adaptations along the Prairie Margin: Site Excavations and Synthesis of Prehistoric Archaeology, edited by Daniel E. McGregor and James E. Bruseth, pp. 185-195. Richland 
Creek Technical Series, Volume III. Archaeology Research Program, Institute for the Study of Earth and Man, Southern Methodist University, Dallas.

McGregor, Daniel E., and James E. Bruseth, editors 1987 Hunter-Gatherer Adaptations along the Prairie Margin: Site Excavations and Synthesis of Prehistoric Archaeology. Richland Creek Technical Series, Volume III. Archaeology Research Program, Institute for the Study of Earth and Man, Southern Methodist University, Dallas.

Perttula, Timothy K., and Bo Nelson

2002 Archeological Survey on FM 317 (Athens Loop) at Site 41HE257, Henderson County, Texas, for the Texas Department of Transportation. Archeological and Environmental Consultants, LLC, Austin.

Perttula, Timothy K.

1992 The Caddo Nation. University of Texas Press, Austin.

Richner, Jeffery J., and Reed Lee

1977 Archaeological and Ethnohistorical Survey at Tennessee Colony Lake. Archaeology Research Program, Department of Anthropology, Southern Methodist University, Dallas.

Shafer, Harry J.

1981 Archeological Investigations at the Attaway Site, Henderson County, Texas. Bulletin of the Texas Archeological Society 52:147-178.
Suhm, Dee Ann, and Edward B. Jelks

1962 Handbook of Texas Archeology: Type Descriptions. The Texas Archeological Society, Special Publication No. 1, and the Texas Memorial Museum, Bulletin No. 4, Austin.

Story, Dee Ann

1965 The Archeology of Cedar Creek Reservoir, Henderson and Kaufman Counties, Texas. Bulletin of the Texas Archeological Society 36:163-258.

Story, Dee Ann, and Darrell G. Creel

1982 The Cultural Setting. In The Deshazo Site, Nacogdoches County, Texas, Volume 1, edited by Dee Ann Story. Texas Antiquities Committee, Austin.

Struiver, M., P. J. Reimer, K. Bard, J. W. Beck, G. S. Burr, K. A. Hughen, B. Kromer, F. G. McCormac, J. Plicht, and M. Spurk

1998 Radiocarbon Data Sets. Radiocarbon 40:1041-1083.

Thurmond, J. Peter

1990 Archeology of the Cypress Creek Drainage Basin, Northeastern Texas and Northwestern Louisiana. Studies in Archeology 5. Texas Archeological Research Laboratory, The University of Texas at Austin.

Turner, Sue Ellen, and Thomas R. Hester 1999 A Field Guide to Stone Artifacts of Texas Indians, 2nd ed. Gulf Publishing Company, Houston. 
APPENDIX: Glossary of Technical Terms 

Abrader: Stone tool, often of sandstone, containing one or more grooves made by sharpening of an implement such as a bone awl.

Arrow point: Point used to tip an arrow, which is propelled by a bow.

Atlatl: A device for throwing a dart or spear, consisting of a stick with a thong, hook, or socket attached to one end to hold the base of the projectile.

Awl: Pointed tool, often made of animal bone, for poking holes in materials such as leather.

Bioturbation: Mixing of sediment by biological agents, e.g., burrowing animals and roots.

Burin: Chisel-like stone tool derived from a flake or blade, or made by modifying another tool by using the burin technique to remove the edges parallel to the long axis and/or transversely or obliquely.

Carinated: Refers to a ceramic vessel form with a sharp shoulder.

Celt: Stone axe, presumably used to fell trees or work wood, with faces that have been ground smooth.

Core: Piece of lithic material from which one or more flakes have been removed.

Dart point: Point used to tip a throwing spear or dart, which is propelled by an atlatl.

Debitage: Debris generated by the removal through percussion or pressure of flakes, chips, and chunks to make stone tools.

Drill: Stone tool with a long, narrow blade suitable for boring into softer materials.

Faunal Remains: Animal bones.

Flake: Generally thin piece of conchoidally fracturing stone with a positive bulb of percussion showing that it was removed from the parent piece by percussion or pressure.

Gouge: Generally thick, bifacially modified tool presumed to have been used like an adze.

Graver: Stone tool with a small, beak-like projection used to incise or engrave materials such as bone and clay.

Grog: Crushed fired clay added as temper to clay used in making ceramic vessels.

Hammerstone: Rock used as a hammer, e.g., in making stone tools, crushing nuts, etc.

Interfluve: Upland landform between generally parallel streams.

Lithics: General term used in archeology to refer to stone artifacts.

Macrobotanical Remains: Plant parts large enough to be readily visible to the naked eye, e.g., chunks of charcoal.

Pitted Stone: Stone artifact, often of tabular sandstone, with one or more small pits pecked into its surfaces; usually presumed to have been used as an anvil for cracking hardwood nuts. 
Posthole: Hole, now filled with sediment in archeological contexts, dug to hold a post.

Projectile point: Inclusive term for arrow and dart points.

Radiocarbon Assay: Analysis of organic material to determine its approximate age by measuring the amount of the carbon-14 isotope it contains.

Scraper: Tool with generally thick, unifacially modified edges used to work hides, bone, and wood.

Sherd: A piece of broken pottery.

Survey: Fieldwork to locate archeological remains within the project area for a proposed Transportation Activity, including on-foot examination of the surface, shovel testing, and trenching by mechanical means where appropriate.

Temper: Nonplastic materials added to clay to decrease the risk of cracking when firing ceramic vessels.

Thermoremnant Magnetism: Magnetic fields altered or formed in atoms of iron by heat in excess of $600^{\circ} \mathrm{C}$. Such fields line up with the magnetic field of the planet at the time of exposure to high temperature and will retain that orientation indefinitely.

Transportation Activity: Any proposed project involving the development, design, construction, or maintenance of the state's intermodal transportation system.

Utilized Flake: Piece of debitage that was used as a tool without being shaped or otherwise modified first. 